Int. J. Dev. Biol. 60: 327-336 (2016)

doi: $10.1387 / \mathrm{ijdb} .160420 \mathrm{bk}$

Symposium Report

\title{
Honoring the work and life of Leroy C. Stevens. A symposium as part of the International Stem Cell Initiative Workshop Bar Harbor, Maine, USA. 14-16 October, 2016.
}

\begin{abstract}
Christopher F. Graham ${ }^{1}$, Davor Solter ${ }^{2}$, John D. Gearhart ${ }^{3}$, Joseph H. Nadeau ${ }^{4}$ and Barbara B. Knowles ${ }^{\star, 5}$

${ }^{1}$ Zoology Department, Oxford University, U.K. ${ }^{2}$ Emeritus, Max Planck Society, Germany, ${ }^{3}$ University of Pennsylvania, Philadelphia, PA, USA, ${ }^{4}$ Pacific Northwest Research Institute, Seattle, WA, USA and ${ }^{5}$ Emerita, The Jackson Laboratory, Bar Harbor, ME, USA
\end{abstract}

PREAMBLE In 2016, a symposium was convened in Leroy C. Stevens' honor, in association with a meeting of the International Stem Cell Initiative (ISCI). ISCI, funded internationally, is composed of a group of $\sim 100$ scientists from many countries, under the leadership of Peter Andrews, who have worked together to characterize a significant number of human pluripotent stem cell lines, to monitor their genetic stability and their differentiation into mature cell types and tissues in vitro and in vivo. Those at the ISCI meeting puzzled through one of the thorniest problems in the therapeutic use of the differentiated derivatives of pluripotent stem cells for human therapy; namely, pluripotent stem cells can differentiate into any cell type in the adult organism, but they also have the capacity for unlimited self-renewal, hence if mutated they may have tumorigenic potential. The meeting considered how these cells might become genetically or epigenetically abnormal and how the safety of these cells for human therapeutic uses could be assessed and assured. The symposium was an opportunity to pay tribute to Leroy Stevens and to the basic science origins of this newest aspect of regenerative medicine. It was a time to reflect on the past and on how it can influence the future of our field.

KEYWORDS: Leroy C. Stevens, stem cell, PSC, human therapy, tumor

\section{A walk in the woods}

This symposium was preceded by a walk in the woods on a clear, crisp Indian-summer day in the Sieur de Monts Springs area of Acadia National Park (Fig. 1). This walk for this large number

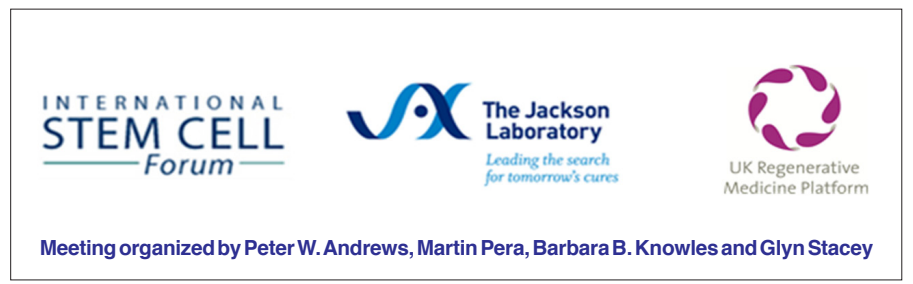

of attendants was led by Leroy's grandson, Jesse Wheeler, Naturalist U.S. National Park Service, Acadia National Park. Jesse's contribution to the memory of his grandfather at the symposium recounted his grandfather's interest in all of nature's creatures and his drive to educate his grandchildren about them. But most of all he imparted his grandfather's love for the beauty of his natural surroundings on Mt. Desert Island, Maine

\section{Honoring Leroy C. Stevens - the Symposium}

Leroy Stevens lived from 1920 to 2015 , a time of great discoveries in the developmental biology community. He obtained his undergraduate degree from Cornell University in 1942 and then served in the United States Army in Europe, where he received the Silver Star for gallantry in action, the third-highest military combat decoration that can be awarded to a member of the United States Armed Forces. This honor was personally awarded to Leroy Stevens by General George S. Patton, for his bravery in action in Sicily (Fig. 2). When Stevens returned to the US he enrolled in a graduate school program at the University of Rochester, obtaining his PhD in Embryology, in 1952. This was done under the direction of the prestigious German-born embryologist Johannes Holtfreter (1901-1992), former pupil of the Nobel Prize winner Hans Spemann (1869-1941) in Freiburg (Germany) some time before World War II (Hamburger, 1996). Leroy Stevens spent his entire professional career, from 1952 to 1989, at The Jackson Laboratory, save for a single sabbatical year, 1961-1962, at the Laboratoire d'Embryologie

Abbreviations used in this paper: EC, embryonal carcinoma; ES, embryonic stem; ISCI, International Stem Cell Initiative Workshop; TGCT, testicular germ cell tumor.

\footnotetext{
*Address correspondence to: Barbara B. Knowles. The Jackson Laboratory, 600 Main Street, Bar Harbor, ME 04609, USA e-mail: bbk4@me.com (iD) http://orcid.org/0000-0002-2597-5619
}

ISSN: Online 1696-3547, Print 0214-6282 
Nogent sur Marne, where he was a Guggenheim Fellow.

\section{Multipotency before 1967}

\section{Christopher Forbes Graham}

Prof. Graham, DPhil, FRS, Emeritus Professor Oxford University has been involved in mammalian embryology research since the 1970s. Chris, himself a student of Sir John Gurdon, the 2012 Nobel prize winner who discovered that nuclei from mature amphibian cells can be reprogrammed to pluripotency, worked with and trained a number of next generation investigators in this field. Chris' expertise is in the control of development in plants and animals. His presentation sets Leroy Stevens work in the science of development and pluripotency of the time.

\section{Contemporary publications 1952-1967}

During the period 1952-1967 Roy Stevens' work was probably best known in the mouse-centric research institutes in the USA and UK. In and after 1967 all developmental biologists should have taken note of his work: Roy published a review in Advances in Morphogenesis (Stevens 1967) and Barry Pierce echoed it in Current Topics in Developmental Biology (Pierce 1967). The present note is about studies on multipotentiality that were published when Roy was doing his pioneering work on testicular tumours in this period.

\section{Plant studies}

Plant studies of multipotency were well ahead of those in animals, with reviews and controversy in Science about the necessity, or otherwise, of coconut milk to make single phloem (nutrient transporting) cells give rise to an entire plant. An optimistic interpretation of the evidence was published in 1964 (Steward 1964). Meticulous studies of cell wall patterns suggested that single root tip cells could give rise to all the cell types of the above or below ground parts of a limited number of plants (reviewed by Clowes 1959). Here a stem cell niche was described, namely the very slow cycling quiescent or cytogenerative centre, which could give rise to all the tissues of the root. The cell wall patterns provided indirect evidence and the interpretation depended on the reasonable assumption that no cell slipped past another.

\section{Totipotency of amphibian cell nuclei}

This totipotency became well established in the 1950's, first with the evidence that many cells of the frog Rana pipiens blastula (5,000 cell stage) could donate nuclei to recipient enucleated eggs and code for the development of early stage tadpoles (Briggs \& King 1952). The follow up work made the demonstration of totipotency complete because donor nuclei taken from gut cells with their characteristic brush border could encode formation of a complete fertile frog (Gurdon 1958). In both studies, the success of the operation decreased as the stage of the frog from which the donating nuclei increased. Consequently, it was possible at that time to believe that nuclear totipotency decreased as the cells differentiated. Possibly the most important conclusion from both studies at this time was that egg cytoplasm could "reprogramme" the donor nucleus to code for the development of a variety of cell types.

\section{Whole cells had a more limited potency}

The classic, well cited study in mammals was with the blood system, where suspensions of the bone marrow or fetal liver could
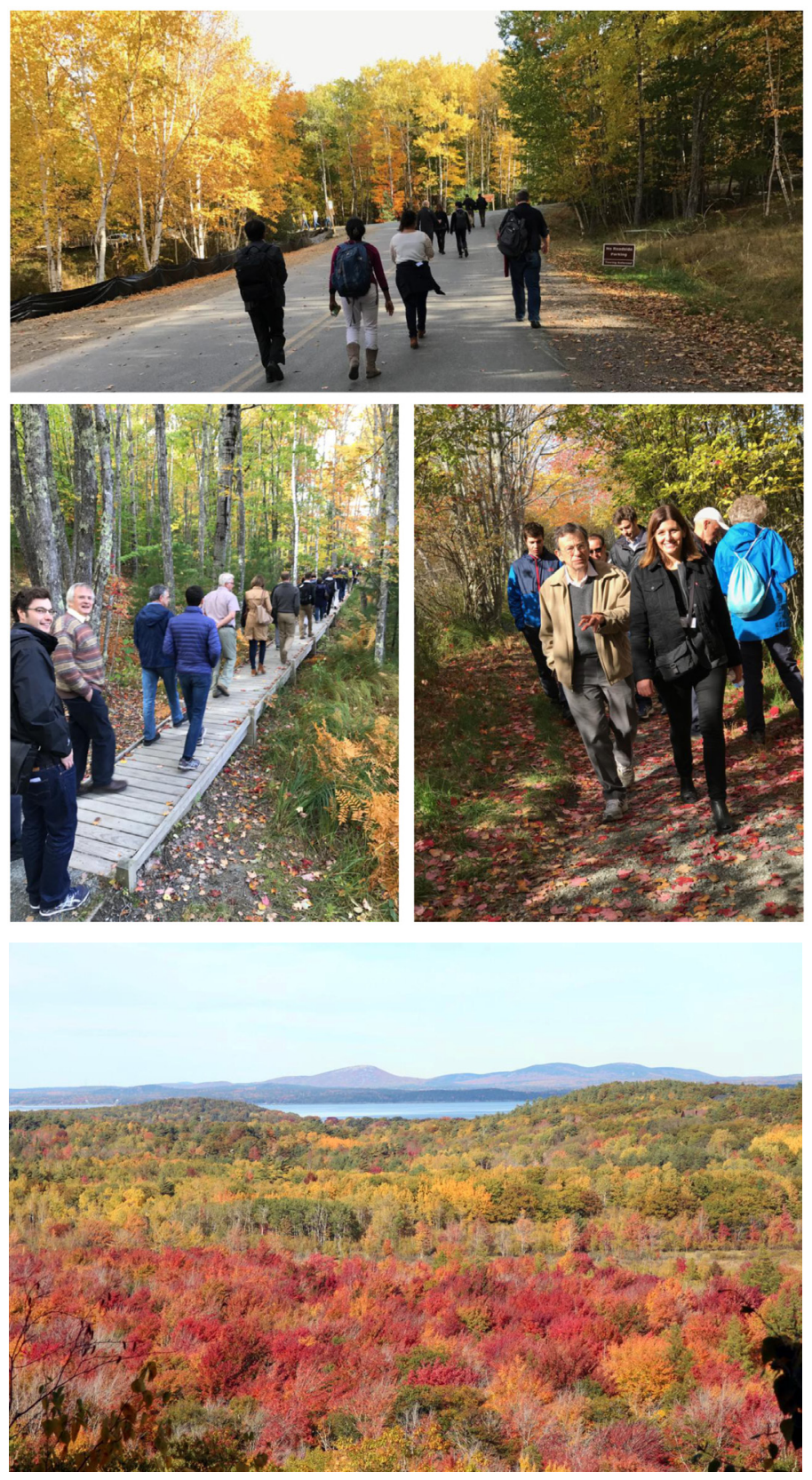

Fig. 1. The Walk in the Woods, October 15, 2016, members of the ISCI, with a view of Frenchman Bay.

give seed cell colonies (CFU's) when injected into an irradiated host (Till \& McCullough 1961). These colonies contained cells from the lineages leading to megakaryocytes, erythrocytes, mast cells and myeloblasts. As the authors pointed out, their demonstration of multi-potent single cells was only flawed because there were a few clumps of cells in their original suspension and these clumps might have contained individual cell precursors of each variety of cell type in a colony. In short, these observations probably demonstrated multi-potency of single cells in the blood system but a tiresome sceptic could still doubt. Also, while Roy was doing his pioneering in mammals, there was a frequent view that there were multipotent stem cells in the stump of regenerating amphibian limbs. It is a pleasure to record that while it looks as if the cells in 
the wounded stump are all alike, there is no transformation of one tissue type to another, at least in the adult newt Cynops pyrrhogaster (Tanaka HV, 2016). This article deposits much speculation into the dustbin of history.

\section{Transdetermination in Drosophila}

Ernst Hadorn carefully analyzed the behaviour of fruit fly imaginal disks over one hundred transplant generations (Hadorn 1966). These imaginal discs, discernable and discrete cellular structures found in different discrete parts of the larva, upon metamorphosis form specific adult structures. For instance, there are larval paired disks that will give rise in the adult to legs, others for antennae, wings, eyes and so on. By cutting these discs into pieces, transplanting them and letting the larvae metamorphose to adult flies, and repeatedly transferring discs to other larvae it was possible to discern whether a disk could retain its memory of the part of the fly into which it would develop. If it had started as a wing disk, the transplanted piece usually formed part of a wing in the adult fly. The peculiarity was that disks could forget their origins and turn into a recognizable structure of some other adult body part. They were said to have been transdetermined from one organ into another, with the change occurring in several cells at the same time. In hindsight these results suggested there were perhaps multi-potential stem cells in the original disk which allowed for this transdetermination by the other groups of cells in the disc. The events remain largely mysterious (McClure \& Schubiger 2007) but the conclusion from these notes is that at the time biologists were desperate for the demonstration of really multipotent animal cells that could rival if not exactly match the totipotent plant cells.

As soon as Roy's work became well known (Stevens 1967), he was feted at international meetings. He dispersed samples of his tumours around the world, most notably to Pierce in the USA but also to Ephrussi and Jacob in France, and Hooper, Evans and Martin in the UK and elsewhere, fomenting a new branch of mammalian developmental biology (Fig. 3).

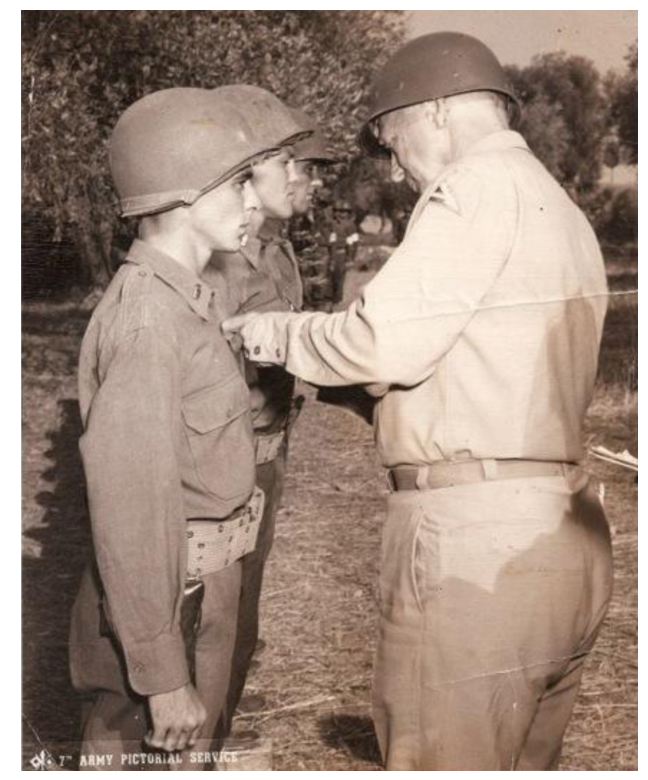

Fig. 2. Leroy Stevens receiving the Silver Star from General George S. Patton, US Army in an olive orchard in Sicily, November 12th, 1943.

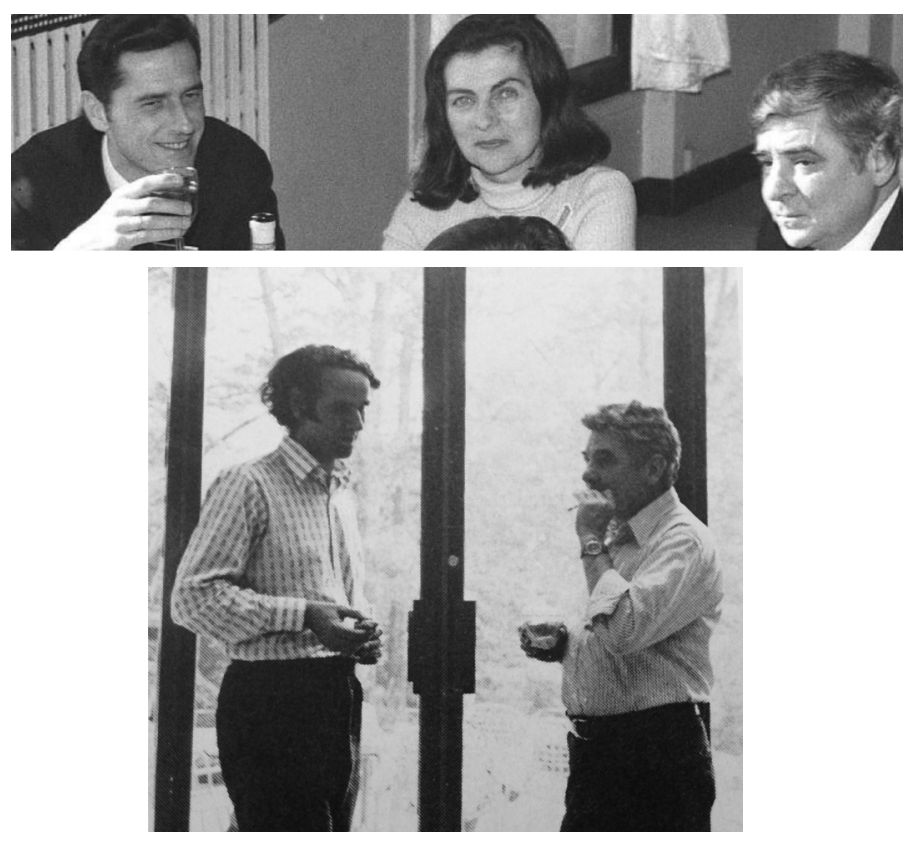

Fig. 3. (Top) Krzysztof Tarkowski, Anne McLaren and Roy Stevens in 1975. (Bottom) Chris Graham and Leroy Stevens.

\section{Roots and branches}

\section{Davor Solter}

Dr. Solter M.D. PhD, Emeritus Director Max Planck Institute of Immunbiology and Developmental Biology, obtained his M.D. and Ph.D. at the University of Zagreb, Yugoslavia (now Croatia) working with Nikola Skreb, an esteemed European Developmental Biologist. Davor, a member of the Academia Europeae and the American Academy of Arts and Sciences, received the March of Dimes Prize in recognition of his discovery of genomic imprinting. Jamie Thomson, who derived the first human embryonic stem (ES) cell lines (Thomson et al., 1998) had years earlier obtained his Ph.D. from the University of Pennsylvania, working with Davor at the Wistar Institute. Davor's early work grazed that of Leroy Stevens.

\section{Roy's oeuvre}

At the time when Leroy Stevens joined The Jackson Laboratory in 1952, animal models for studying experimental teratomas/ teratocarcinomas did not exist. The detailed studies reported by Slye (Slye et al., 1919, 1920) indicated only 1 ovarian teratoma out of 22,000 autopsies and not one testicular teratoma out of 19,000 autopsies. Remarkably in his early days at The Jackson Laboratory Stevens described about a $1 \%$ incidence of testicular teratoma in the 129 mouse strain (Stevens \& Little, 1954). Indeed, despite this relatively low testicular germ cell tumor incidence Stevens succeeded in subsequent years to analyze in depth the biology of spontaneous testicular teratoma. Furthermore, In the subsequent 15 years Leroy Stevens and Barry Pierce described the biology of testicular teratoma and established a model of experimentally induced teratocarcinoma (Stevens 1967; Pierce, 1967).

\section{Stevens' quest to increase teratoma incidence}

This led to the discovery of a great deal of interesting biology. Spontaneous testicular teratoma originates in the seminiferous 
tubules as small clusters of embryonal cells which often resemble early post-implantation mouse embryos and are thus called embryoid bodies (Stevens 1959). The incidence of testicular teratoma in the left testis was 2 to 3 times higher than that in the right testis, most likely due to the small anatomical differences in blood supply between the two. This was confirmed to be the case when Stevens introduced the iv mutation (situs inversus) into the 129 mouse strain and observed the incidence of teratomas in the right and left testis was now reversed but the overall incidence was unchanged (Stevens, 1983). By introducing Steel (SI) into 129 strain an increased incidence of testicular teratoma to about $5 \%$ (Stevens \& Mackensen 1961). In addition to genetic influences on teratoma incidence, they found that environmental influences also play a role, i.e. tumors will not develop in the cryptorchid testis (Stevens \& Mackensen 1961). The role of genetics in controlling the incidence of spontaneous teratoma was further emphasized when Stevens observed a spontaneous occurring mutation in $129 / S v$ strain that increased teratoma incidence to 30\% (Stevens 1973). Stevens named this mutation ter, but it took over 30 years to molecularly identify the Ter mutation in the Dnd1 gene (Youngren et al., 2005). Mutation is probably the cause for spontaneous ovarian teratoma in the LT mouse strain (Stevens \& Varnum 1974) however, this mutation has not yet been molecularly characterized. The ovarian teratoma in the LT strain of mice likely develop from parthenogenetically activated ovarian oocytes, since all stages of preimplantation and early postimplantation development can be observed in the sectioned ovaries and the teratoma appears to develop from disorganized embryos (Stevens \& Varnum 1974).

\section{Stevens suggested the cell of origin of testicular teratoma is also a germ cell}

He suggested that this germ cell, through a process he called ephebogenesis, developed into an embryo-like structure (Stevens 1959). Stevens confirmed this suggestion by a clever experiment involving genital ridge transfers (see later) from fetuses produced by crossing $129 / \mathrm{SI} /$ + by $129 / \mathrm{SI}+$ +. The homozygous S/mutation causes, among other things, the absence of germ cells in the genital ridge. By transferring genital ridges from such fetuses Stevens showed that teratoma appeared in genital ridge-derived testes of wild type and heterozygous fetuses but never in the germ cell-less testes derived from genital ridges of SI/SI fetuses (Stevens 1983). Obviously, at that time, molecular genotyping of genital ridges was not possible so Stevens used an ingenious method to genotype each individual grafted genital ridge. To each genital ridge graft to the testes he added a small piece of dorsal skin from the same fetus, which developed hair in the graft. The hair in wild type homozygote and heterozygotes was black, and in homozygous mutants was white (Stevens 1983). Absence of teratomas in testes derived from S/ genital ridges clearly demonstrated the germ cell origin of testicular teratomas.

Spontaneous testicular teratocarcinomas can be retransplanted into syngeneic hosts

In these hosts, after intraperitoneal injection, the teratocarcinomas grow as an ascites tumor composed of small structures with an embryonal carcinoma cell core surrounded by epithelial cells resembling endoderm, the so-called embryoid bodies (Stevens 1958). Using these retransplantable teratocarcinomas Kleinschmidt

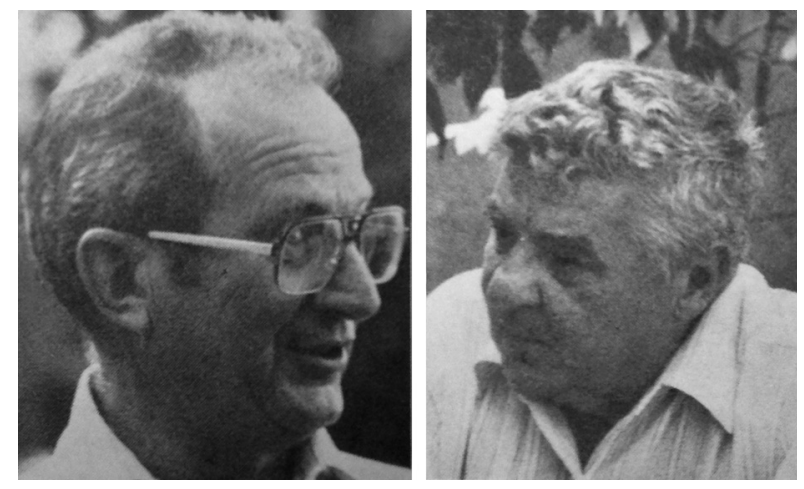

Fig. 4. Barry Pierce (left) and Leroy C. Stevens (right), at the Cold Spring Harbor meeting in September 1982.

\& Pierce in 1964, established the stem cell basis of cancer by showing that a single embryonal carcinoma cell injected into the peritoneal cavity faithfully reproduces the entire spectrum of tissues, malignant and differentiated, found in the original teratocarcinoma.

\section{Stevens also devised a method to produce experimental testicular teratomas}

He did this by grafting fetal genital ridges into testes of adult hosts (Stevens 1964). Grafted genital ridges develop into testes which contain initially multiple foci of embryonal carcinoma cells which then follow the same developmental path as spontaneous testicular teratoma. The ability to develop into teratoma is lost in genital ridges from fetuses older than 14.5 days (Stevens 1966). The genetic and environmental influences affecting the development of genital ridge-derived teratoma were very similar to those influencing the development of spontaneous tertatoma although they were not restricted to the 129 strain but also appeared in grafts from several other mouse strains (Stevens 1970; Stevens 1983).

\section{Teratoma will also develop from embryos grafted to extra-uterine sites}

Such sites include the testis (Stevens 1968; Stevens 1970) or under the kidney capsule (Solter et al., 1970). These experiments provided the conclusive evidence that the appearance of malignant tumors is entirely due to the disturbance of the normal developmental program.

In the period between 1954 and 1970 two laboratories, one in Bar Harbor led by Stevens and one in Colorado led by Barry Pierce were essentially the only ones working with experimental mouse teratomas and teratocarcinomas (Fig. 4). The unique features of this tumor finally produced wider interest, drawing more and more laboratories into this area of research. This expanded interest is best summarized by the Proceedings of two meetings (Sherman \& Solter 1975; Martin, Strickland and Silver 1983). Stevens legacy today includes the derivation of pluripotent mouse and human embryonic stem cell lines (Evans \& Kaufman 1981; Martin 1981; Thomson et al., 1998). Mouse embryonic stem cells in combination with homologous recombination enabled us to manipulate the mouse genome at will and to follow the phenotypic consequences of particular genes in the adult organism. Pluripotent human embryonic stem cells represent the basis of today's hope for stem and tissue replacement therapy. 


\section{Pluripotentiality and problems}

\section{John Gearhart}

Prof. Gearhart, Ph.D., the James Effron University Professor at the University of Pennsylvania, and the founding Director of the University of Pennsylvania's Institute for Regenerative Medicine, obtained his Ph.D. in Genetics and Development at Cornell University. He joined Beatrice Mintz' laboratory at the Fox Chase Institute for Cancer in Phladelphia as a postdoctoral fellow in 1970. In 1975, John began his academic career at The John Hopkins University, where he derived human pluripotent stem cells from fetal genital ridges (EG cells) in 1998 (Shamblott et al., 1998), a banner year for human pluripotent stem cells.

\section{A personal history of pluripotency}

Hubert Condamine introduced me to embryonal carcinomas (ECs) and to the work of Roy Stevens and others in 1970. Hubert and I had just joined the laboratory of Beatrice Mintz. Hubert came from Francois Jacob's laboratory (others in that laboratory working on these cells included Karen Artz and Charles Babinet) and I was a newly minted Ph.D. with a dissertation in Drosophila genetics from Cornell. Apparently Jacob had become interested in these cells as a result of research from Boris Ephrussi's group (Kahan \& Ephrussi 1970) in Gif-sur-Yvette with Brenda Finch-Kahan and Martin Hooper. Ephrussi had obtained cells (402III, derived from a teratocarcinoma by Roy Stevens, in 1958) from G. Barry Pierce, to study in vitro differentiation and its suppression in somatic cell hybrids. Lewis Kleinsmith and Pierce had demonstrated the multipotentiality of single embryonal carcinoma cells (Kleinsmith \& Pierce 1964), and by 1970 other laboratories interested in mammalian developmenthad published significant studies on teratocarcinomas (Davor Solter, Nikola Skreb, Ivan Damjanov and Gordon Sato (Solter et al., 1970; Rosenthal et al., 1970) while others began work and had publications in mid-'70's and beyond (Chris Graham, Arnold Levine, Gail Martin, Martin Evans, for example). The embryonal carcinomas were cautiously viewed as a model of mammalian embryogenesis because of their resemblance to an early embryo as the tumor developed spontaneously, or when grown in suspension (the so-called embryoid bodies), where these cells subsequently differentiated into a variety of cell types.

I first met Roy Stevens in 1972 at a NATO-sponsored meeting on Mosaics, in Venice, and the circumstances were unforgettable. A group of us, including Roy, had gone to dinner and continued the evening in the true meaning of the word symposium, that is, drinking heavily (and discussing science). Roy disappeared sometime during the 'symposium' and concern about him was raised when we returned to the hotel quite late and found he had not returned and by that hour all the drinking establishments were closed. We were concerned he may have toppled into a canal, as a worst case scenario, and accordingly we set out to find him, without success even after engaging the Carabinieri. He did not appear at the meeting the next morning but later in the day a scrawled message note was found, which had been overlooked at the hotel, addressing us in ribald language stating that he had always wanted to ride on the Orient Express to Istanbul. I later learned that he boarded the train in Mestre around midnight and although the trip did not meet his high expectations, he enjoyed it nonetheless.

Roy extended an offer for me to visit him at the Jackson Lab, which I did later that year. I spent several days at his elbow learning how to passage cells, to accomplish some of the surgeries he utilized,

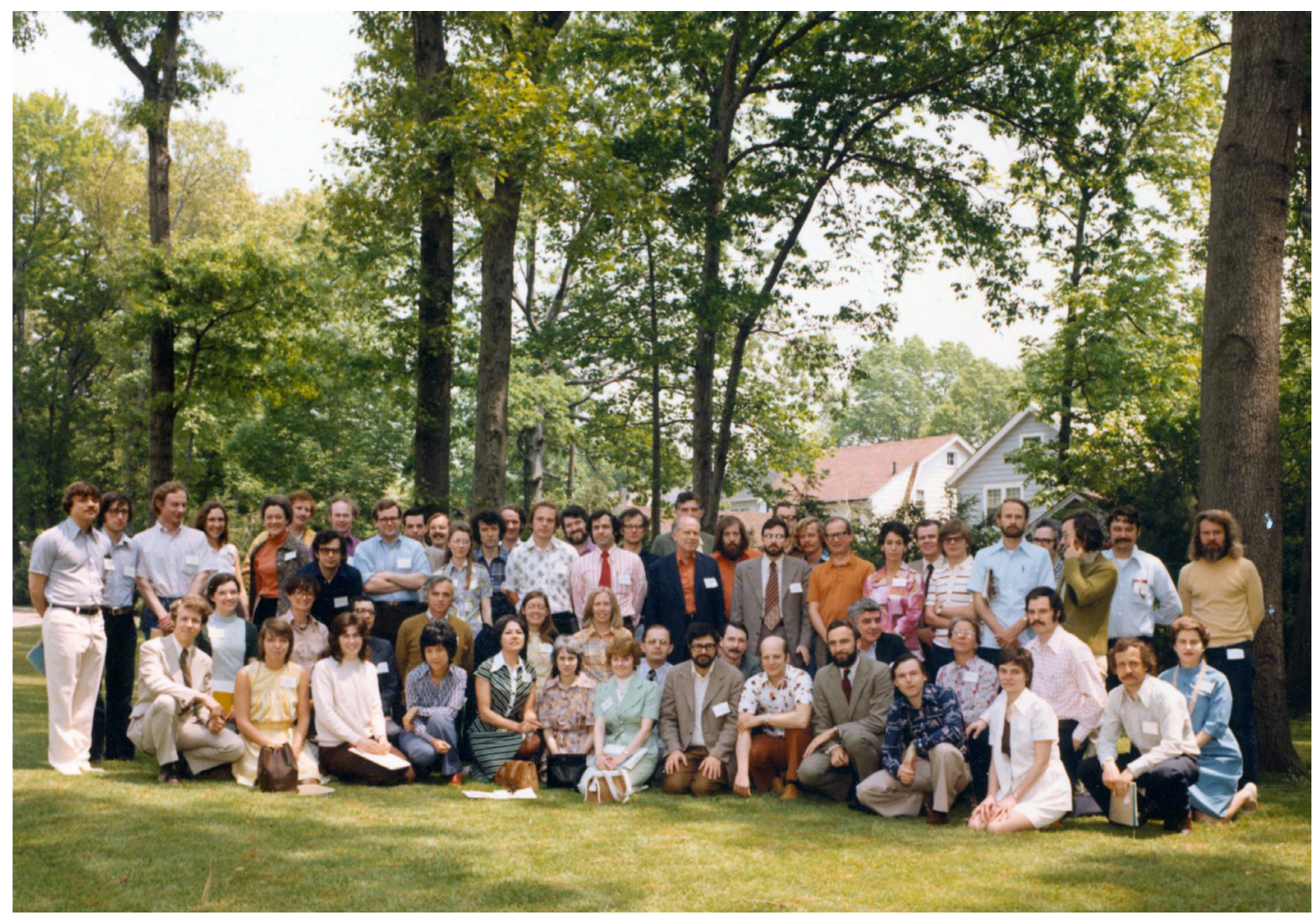

Fig. 5. Participants at the 1975 Nutley symposium, including Leroy Stevens, Barry Pierce, Ralph Brinster, Bea Mintz, Gail Martin, Chris Graham, John Gearhart, Barbara Knowles, Davor Solter and many others mentioned in this paper. 
and of course, to recognize a lot of the histology/pathology of the tissues arising from the transplants. As with subsequent teacher/ student visits, he was gracious, patient, thorough, candid, never in a hurry, and displayed a wonderful sense of humor. I didn't realize that this initial visit was the beginning of a strong friendship and many visits over 30 years. Subsequently he provided the Mintz laboratory with the OTT6050 intraperitoneally maintained tumor line (derived from a 6-day male 129SvSIJCP embryo grafted to a testis) as well as breeding animals to maintain the tumor. Roy was very generous in sharing his materials, the OTT6050 probably became the most widely distributed of his in vivo passaged teratoma lines. Mintz' laboratory then began various timely studies on cell differentiation and more.

In 1975 a large number of the prominent investigators working with embryonal carcinoma cells ECs, (Fig. 5), met in Nutley, $\mathrm{NJ}$, presenting their work. This was probably the zenith of work on ECs as in the early 1980's mouse embryonic stem (ES) cells were derived and the field turned to these cells as the model for developmental studies as ES cells were not intrinsically neoplastic. The Proceedings of this meeting were published and give an excellent sampling of a variety of studies on EC cells (Sherman and Solter, Eds, 1975).

Mouse experimental chimeras are used to test the developmental potential of stem cells. In the case of pluripotent stem cells, the pluripotent cells are placed into the blastocyst cavity adjacent to the normal inner cell mass and the resultant animals are assayed for their contribution to any and all tissues. The first report on chimeras with EC cells was made and published by Ralph Brinster (Brinster 1974). He presented a mosaic animal that had small patches of its coat color hair derived from the embryonal carcinoma (EC) cells, indicating that these tumor cells could contribute to somatic tissues. A number of reports followed from other laboratories with similar, but more robust chimerism using EC cells. These results were remarkable in that the EC cells, while tumorigenic, could be 'normalized' (the term used at the time) to contribute to somatic tissues of the chimera without forming tumors. There was one exceptional chimera, and the only one ever reported, reported to demonstrate germ line transmission, resulting in normal progeny of the genotype derived from the EC cell used. In a series of papers, debuted by Mintz at the 1975 Nutley meeting, and subsequently published by Karl IIImensee and Beatrice Mintz, "Terry Tom", a chimeric mouse made from a single EC cell (from OTT6050) transferred to the blastocyst cavity of a female embryo, was described. This chimera was almost entirely of the EC genotype and it produced normal progeny, the EC cell contributed to the germline (Mintz \& IIImensee 1975, Illmensee \& Mintz 1976). Great skepticism on the provenance of this mouse mounted over the years, fueled not only by others failing to reproduce the results but also by irregularities in the publication of a key paper validating the karyotype of progeny from "Terry Tom" (Cronmiller \& Mintz 1978). The controversy over this mouse was further reinforced when a few years later several high visibility publications on nuclear transfer experiments with mouse embryos, from Mintz' former co-author who performed the "Terry Tom" experiments, were also found not credible, not reproducible and inconsistent with a growing number of other studies.

For the decade, well into the '80's, in which the above related events played out, this issue weighed heavily on Roy. This was

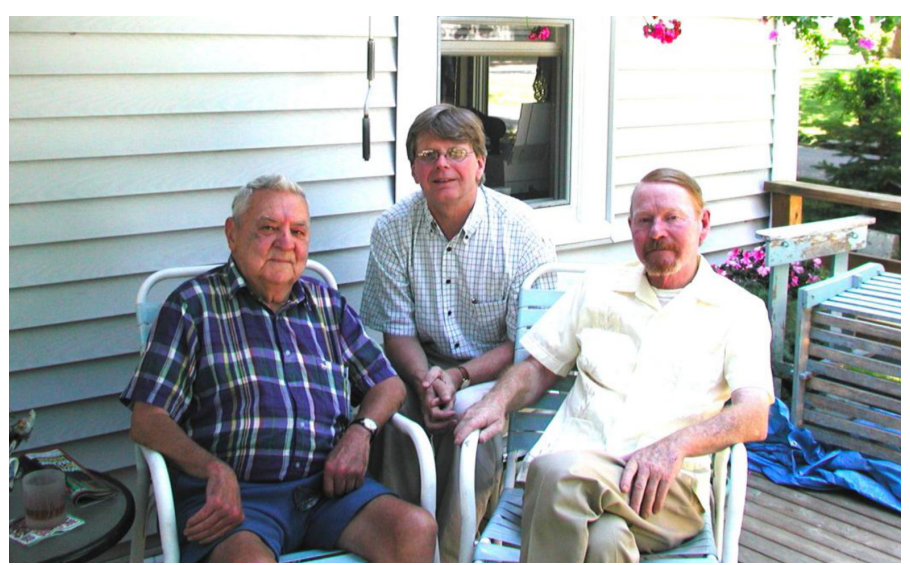

Fig. 6. From left to right: Leroy C. Stevens, John Gearhart and Peter Hoppe in Bar Harbor, 2001.

his area of science, he knew the players well, some of the questionable work was conducted in Jackson Laboratory facilities, and he just couldn't reconcile all that had transpired, with its impact on science, people he knew, and with his own idea of fair play. I visited Bar Harbor annually, as I had the lucky perk of teaching in the Short Course in Experimental and Mammalian Genetics, an ongoing collaborative effort between Johns Hopkins Medicine (spear headed by Victor McKusick and Dave Valle from JHU and scientists at the Jackson Laboratory). This enabled me to visit with Roy frequently. Our conversations centered for many years on the science involving embryonal carcinomas, embryonic stem cells, embryonic germ cells, nuclear transfer, multipotentiality, pluripotentiality, oogenesis, and spermatogenesis. He grumbled frequently about the growing competitive

nature of science taking the fun out of actually doing science. We spent more time outside of the laboratory enjoying the beauty of Mount Desert Island talking science and always eating lobster (with no sides - at his insistence) no matter the time of day. Later as his health declined, we mostly just sat and enjoyed the beauty of different locations on the Island with little conversation. (Fig. 6). I was fortunate to get to know Roy well and benefited not only from his vocational generosity but also his enjoyable company.

\section{Genetics and epigenetics of inherited teratocarcinoma risk}

\section{Joseph Nadeau}

Dr. Nadeau, Ph,D., Principal Scientist at the Pacific Northwest Research Institute, was born and educated in Maine. It was his good fortune to have attended the Jackson Laboratory summer student program where he worked in Leroy Stevens laboratory, and with whom he published his first paper. After Joe received his Ph.D., and did a postdoctoral fellowship at a Max Planck Institute in Tubingen, Germany, he returned to the staff of The Jackson Laboratory where he founded and directed the Mouse Genome Database Informatics and the Mouse Gene Expression Database Programs, continued to this day by his colleagues. This effort dispersed knowledge of the mouse throughout the scientific community and provided a huge stimulus to the work of all mammalian geneticists. Joe is now exploring epigenetic and genetic control of complex traits. 


\section{Lessons from a deadend}

Our scientific legacy is in part the work we do and also the subsequent findings our work enables. Steven's work is notable not only for what he demonstrated, but also because it opened doors for others to follow in his path to make deeper discoveries. In that spirit, I start with some of Roy's discoveries and then show where they led me in my own work. Perhaps the Stevens' most important contribution was to provide the experimental evidence for the stem cell origin of cancer (Stevens 1964, Stevens 1967); Barry Pierce independently provided similar evidence (Kleinsmith \& Pierce1964); see review (Sell 2010). This is an example of great work the significance of which was inexplicitly over-looked, barely remembered, and was not really pursued. Stevens is also widely recognized for contributing to the derivation of embryonic stem (ES) cells in vitro and to their genetic engineering. This contribution is probably what he is remembered for most, an example of work that enabled even greater discoveries. Other aspects of his work continue to lead to ideas and paradigms about inheritance, Mendel's Laws, and genetic studies. These aspects of Roy's work are also largely overlooked. Here are some highlights:

\section{Genetics}

Stevens (Stevens and Little, 1954; Stevens and Hummel, 1957) showed that the 129 family of inbred strains is unique in its susceptibility to spontaneous testicular germ cell tumors (TGCTs). Stevens was right to wonder about the genes that control this susceptibility. The genes that make 129 different from other strains must be incredibly interesting with respect to their impact on pluripotency in the mother of all stem cell lineages. Stevens made crosses to test inheritance of susceptibility and showed that affected male offspring are exceedingly rare, too rare for conventional approaches to define testicular germ cell tumor (TGCT) susceptibility (Stevens 1981). To address this question, we pioneered an alternative approach making the first autosomal chromosomal substitution strain (CSS) (Matin et al.1999), where a 129-derived chromosome carrying a candidate gene (Collin et al., 1993) was replaced with the corresponding chromosome from a TGCT-resistant strain (Nadeau et al., 2000). This CSS showed increased occurrence, from a $7 \%$ baseline to more than $75 \%$, of affected males. Another CSS provided complete resistance both to TCGTs as well as to ES cell growth in vitro (Anderson 2009). Surveys of these and other 129 strains have even revealed germ cell-derived metastases (Zechel 2011), which were never observed in Stevens'strains and model. CSSs have great potential for studying the genetics of pluripotency. More generally, these and other CSSs are revolutionizing genetic and functional studies of complex traits with the discovery of unprecedented numbers of complex trait genes, pervasive epistasis, and systems properties (Shao et al., 2008, Spiezio et al., 2012; Buchner \& Nadeau, 2015).

\section{Modifier genetics}

Stevens turned his attention to hypothesis testing based on single gene mutations that had been transferred to the 129 background (Stevens, 1964; Stevens, 1981). Results for Steel mutations in the Kitl gene are especially interesting. Deficiency of germ cells in Steel mutant mice provided a test as to whether loss of these cells affected TGCT-susceptibility and hence whether germ cells are needed for tumorigenesis. In fact, Steel increased TGCT risk 2- to 3 -fold in a dosage-dependent manner, suggesting that reducing stem cell numbers increases susceptibility, a phenomenon that is still not understood. Curiously, loss of TGCTs was found with some Kit/mutants but not others, and not for mutations in KIT, the germ cell receptor KIT ligand, a curious observation for a ligand-receptor signaling system (Heaney et al., 2008). This issue was resolved by showing that only those mutations that resulted in loss of the transmembrane, but not the soluble isoform, affected susceptibility. Recently, several studies of TGCT-susceptibility in humans found that KITL genetic variants show the strongest association with TGCT risk (Kanetsky et al., 2009). Stevens was one of the pioneers of an approach that is now known as modifier genetics, where single gene variants modulate the phenotype in mice with simple or complex traits (Nadeau 2001; Nadeau \& Topol 2006; Harper et al., 2015). Similar approaches are being pursued to test for modifier genes in humans (Chen et al., 2016), genes that hold the promise of defining networks of disease function as well as presenting new ways to control pathologic outcomes.

\section{Gene discovery}

An important breakthrough derives from work with a mutation that Stevens originally called Ter (Stevens 1973). This mutation dramatically increases occurrence of TGCT-affected males, from $7 \%$ of $129 / \mathrm{Sv}$ wildtype males to $17 \%$ in $129-\mathrm{Ter}+$ + heterozygotes and $94 \%$ in $129-$ TerlTer homozygotes. But these striking effects are found only on the 129 background. On other backgrounds, Ter reduces fertility in heterozygotes and causes sterility in homozygotes, suggesting that 129 -derived genes remain to be discovered. This mutation was shown to result from a point mutation in the Deadend1 gene (Youngren et al., 2005). Sequence analysis shows motifs that suggest RNA binding activity and homology with genes involved in RNA editing. Interestingly, Dnd1 controls access of miRNAs to their mRNA targets, several of which are involved in cell cycle control, pluripotency and apoptosis (Kedde et al., 2007). In zebrafish, mice and several other species, Dnd1 is required for germ cell differentiation (Bustamante-Marin et al., 2013).

\section{Epigenetic inheritance}

Mutations in Dnd1 and several other TGCT genes not only increase risk in carriers but also affect offspring risk in a parentof-origin manner. In some cases, reduced risk persists for multiple generations (Lam et al., 2007). Persistence of reduced risk was one of the earliest discoveries of transgenerational inheritance of cancer.

\section{Fertilization}

Finally, a fundamental tenet of inheritance in sexually reproducing organisms, such as humans and laboratory mice, is that genetic variants combine randomly at fertilization, thereby ensuring a balanced and statistically predictable representation of inherited variants in each generation. This principle is encapsulated in Mendel's First Law of Segregation, which is thought to be nearly universal, applying to most genes under most circumstances in most species. We recently discovered, through our own work in mice and that of others in the literature, examples where deviations from these expectations are remarkably strong, and often misinterpreted as early embryonic lethality (Nelson et al., 2012; Zechel et al., 2013; Nakouzi \& Nadeau 2014). Normal litter size and the absence of dead embryos argue against embryonic lethality as a cause of these departures from Mendelian expectations. There is consistent evidence across six genes that sperm and egg join 


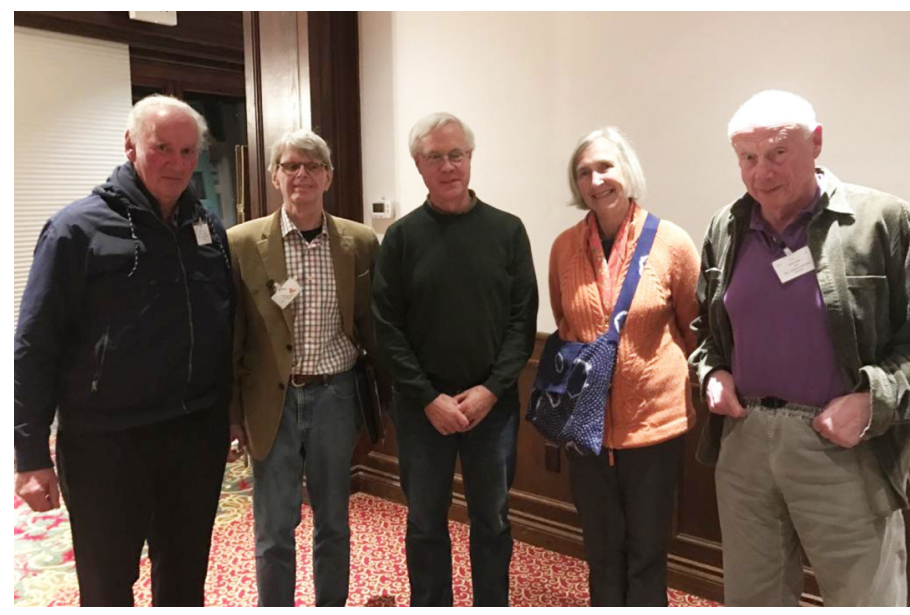

Fig. 7. 2016 International Stem Cell Initiative (ISCI) Workshop symposium chair and speakers, from left to right: Chris Graham, John Gearhart, Joe Nadeau, Barbara Knowles and Davor Solter.

non-randomly at fertilization based on their genetics. Three of these genes, including Dnd1, not only bias fertilization but also control TGCT-risk in both a conventional and an epigenetic manner. This suggests that TGCT-risk, epigenetic inheritance and fertilization bias are each manifestations of germline anomalies. This unexpected discovery about genetically biased fertilization could yield insight into the molecular and cellular biology of sperm, eggs and fertilization, with implications for studies of inheritance, reproduction, population genetics, and genetic counseling for birth defects and adult conditions.

The discoveries that Stevens made together with those made subsequently, on the back of his original findings, illustrate his unusual instinct for important biology and interesting questions.

\section{Contributions from scientific colleagues}

\section{Juan Aréchaga}

Juan Aréchaga MD, PhD, Professor Emeritus at the University of the Basque Country (UPV/EHU) conducted an interview with Barry Pierce (Aréchaga, 1993) in which Pierce describes his close scientific relationship with Roy Stevens: "I also learned a lot of embryology from Roy Stevens. I started working with the Fekete ovarian teratocarcinoma in 1956 and then discovered Roy Stevens' strain 129 testicular tumors. In 1954 Roy published a paper on spontaneous strain129 teratomas with C.C. Little. He even described embryoid bodies in them. I learned how to mass produce the embryoid bodies by converting the solid tumor to an ascites variant, and immediately told Roy. He was very interested in these bodies and when he published a paper some months later he was very gracious to me and we became very close friends. He was interested in the genetics of testicular tumors and made important discoveries in that field. He was also interested in the experimental production of the tumors using embryo transplants. This became a very important tool in testicular tumor research, as did our discovery of mass producing embryoid bodies. It was a very interesting situation. He was interested in the genetics and the development of the tumors. I was interested in their neoplastic aspects, the relationship of embryonal carcinoma to their differentiated derivatives and the possibility of developing differentiation therapy. I was particularly interested in why, when the histotypic differentiation occurred, abrogation of malignancy resulted". The importance of the frequent correspondence between Roy Stevens and Barry Pierce at that time was briefly summarized by François Jacob in the Concluding Remark of the 1982 Cold Spring Harbor meeting on Teratocarcinoma Stem Cells: "Twenty years ago, a meeting on teratocarcinoma would have consisted of a dialogue between Roy Stevens and Barry Pierce".

\section{John Eppig}

John Eppig, PhD. Professor Emeritus The Jackson Laboratory, initially came to The Jackson Laboratory as a visiting fellow with Leroy and subsequently joined the Jackson Laboratory Staff. John recounted several incidents that reflected Leroy Stevens deep, abiding sense of humor. One, regarding the regulation of the height of the venetian blinds at the Jax, the height of which was strictly adjusted by the extremely fastidious Laboratory Director each evening and then routinely destroyed each morning by Leroy's counter adjustments, was particularly apt.

\section{Lenny Shultz}

Lenny Shultz, Ph.D. Professor The Jackson Laboratory a fellow fisherman told the story of going to one of his favorite mackerel fishing spots. Finding Leroy there, sitting on an upended white plastic container he said "Hi Roy, are the mackeral biting?" "Nope", he said "they aren't". "So why" says Lenny "are you sitting here?" "Oh" Roy said "its just so beautiful." (Fig. 1).

There you have it, the four symposium speakers (Fig. 7) made their case as to the past and continuing scientific contributions of Leroy Stevens, and his family and colleagues saluted his humanity.

\section{Acknowledgements}

The authors would like to express their appreciation to The International Stem Cell Forum, The UK Regenerative Medicine Platform, The Jackson Laboratory, Stem Cell Technologies, Thermofisher Scientific and Ajinomoto Corporation for sponsorship of this symposium.

\section{References}

ANDERSON PD, NEWSON VR, TESAR TJ, NADEAU JH (2009). Genetic factors on mouse chromosome 18 affecting susceptibility to testicular germ cell tumors and permissiveness to embryonic stem cell derivation. Cancer Res 69: 9112-9117.

ARECHAGA J (1993). On the boundary between development and neoplasias. An interview with Professor G. Barry Pierce. Int J Dev Biol 37: 5-16.

BRIGGS R, KING TJ (1952). Transplantation of Living Nuclei from Blastula Cells into Enucleated Frogs' Eggs. Proc Natl Acad Sci 32: 455-463.

BRINSTER R (1974). The effect of cells transferred into the mouse blastocyst on subsequent development. J Exp Med 140: 1049-1056.

BUCHNER DA AND JH NADEAU (2015). Contrasting genetic architectures in different mouse reference populations used for studying complex traits. Genome Res 25: 775-791.

BUSTAMANTE-MARIN X, GARNESS JA, CAPEL B. (2013). Testicular teratomas: an intersection of pluripotency, differentiation and cancer biology. Int J Dev Biol 57: 201-10.

CAROUGE D, BLANC B, KNOBLAUGH SE, HUNTER RJ, DAVIDSON NO, NADEAU $\mathrm{JH}$ (2016). Parent-of-origin effects of A1CF and AGO2 on testicular germ-cell tumors, testicular abnormalities and fertilization bias. Proc Natl Acad Sci USA 113: $5425-5433$

CHEN R, SHI L, HAKENBERG J, NAUGHTON B, SKLAR P, ZHANG J, ZHOU H, TIAN L, PRAKASH O, LEMIRE M, SLEIMAN P, CHENG WY, CHEN W, SHAH H, SHEN Y, FROMER M, OMBERG L, DEARDORFF MA, ZACKAI E, BOBE JR, 
LEVIN E, HUDSON TJ, GROOP L, WANG J, HAKONARSON H, WOJCICKI A, DIAZ GA, EDELMANN L, SCHADT EE, FRIEND SH (2016). Analysis of 589,306 genomes identifies indivduals resilient to severe Mendelian childhood diseases. Nat Biotechnol 34: 531-8.

CLOWES F L (1959). Apical meristems of roots. Biol. Reviews, 34: 501-527.

COLLIN GB, ASADAY, VARNUM DS, NADEAU JH (1996). DNA pooling as a quick method for finding candidate linkages in multigenic trait analysis: an example involving susceptibility to germ cell tumors. Mammal Genome 7: 68-70.

CRONMILLER C, MINTZ B (1978). Karyotypic normalcy and quasi-normalcy of developmentally totipotent mouse teratocarcinoma cells. Dev. Biol 67: 465-477.

EVANS MJ KAUFMAN, MH (1981). Establishment in culture of pluripotential cells from mouse embryos, Nature 292: 154-156.

GURDON JB (1958). Sexually mature individuals of Xenopus laevis from the transplantation of single somatic nuclei. Nature 182: 64-65.

HADORN E (1966). Konstanz, wechsel und typus der determination und differenzierung in zellen aus Mannlichen genitalanlagen von Drosophila melanogaster nach dauerkulture in vivo. Dev. Biol 13: 424-509.

HAMBURGER, V. (1996). Memories of Professor Hans Spemann's Department of Zoology at the University of Freiburg, 1920-1932. Int. J. Dev. Biol. 40: 59-62

HARPER AR, NAYEE S, TOPOL EJ (2015). Protective alleles and modifier variants in human health and disease. Nat Rev Genet 16: 689-701.

HEANEY JD, LAM MY, MICHELSON MV, NADEAU JH (2008). Loss of the transmembrane but not the soluble kit ligand isoform increases testicular germ cell tumor susceptibitity in mice. Cancer Res 68: 5193-5197.

ILLMENSEE K, MINTZ B (1976). Totipotency and normal differentiation of single teratocarcinoma cells cloned by injection into blastocysts. Proc Natl Acad Sci USA 73: 549-553.

KAHAN, BW, EPHRUSSI B (1970). Developmental potentialities of clonal in vitro cultures of mouse testicular teratomas. J Natl Cancer Inst. 44: 1015-1036.

KANETSKY PA, MITRA N, VARDHANABHUTI S, LI M, VAUGHN DJ, LETRERO R, CIOSEK SL, DOODY DR, SMITH LM, WEAVER J, ALBANO A, CHEN C, STARR JR, RADER DJ, GODWIN AK, REILLY MP, HAKONARSON H, SCHWARTZ SM, NATHENSON KL (2009). Common variation in KITLG and at 5q31.3 predisposes to testicular germ cell cancer. Nat Genet 41: 811-815.

KEDDE M, STRASSER MJ, BOLDAJIPOUR B, OUDE VRIELINK JA, SLANCHEV K, LE SAGE C, NAGEL R, VOORHOEVE PM, VAN DUIJSE J, OROM UA, LUND AH, PERRAKIS A, RAZ E, AGAMI R (2007). RNA- binding protein DnD inhibits microRNA access to target mRNA. Cell 131: 1273-1286.

KLEINSCHMIDT LJ, PIERCE GB, JR (1964). Multipotentiality of single embryonal carcinoma cells. Canc. Res. 24: 1544-1552.

LAM MY, HEANEY JD, YOUNGREN KK, KAWASOE JH, NADEAU JH (2007). Trans-generational epistasis between Dnd1Ter and other modifier genes controls susceptibility to testicular germ cell tumors. Hum Mol Genet 16: 2233-40.

MARTIN G R (1981). Isolation of a pluripotent cell line from early mouse embryos cultured in medium conditioned by teratocarcinoma stem cells. Proc Natl Acad Sci USA 78: 7634-7638,

MATIN A, COLLIN GB, ASADA Y, VARNUM D, NADEAU JH (1999). Susceptibility to testicular germ-cell tumours in a 120.MOLF-Chr 19 chromosome substitution strain. Nat Genet 23: 237-240.

MCCLURE KD, SCHUBIGER G (2007). Transdetermination: Drosophila imaginal disc cells exhibit stem cell-like potency. Int/ J Biochem \& Cell Bio/ 39: 1105-1118.

MINTZ B, ILLMENSEE K (1975). Normal genetically mosaic mice produced from malignant teratocarcinoma cells. Proc Natl Acad Sci USA.72: 3585-589.

NADEAU JH (2001). Modifier genes in mice and humans. Nature Rev Genet2: 165-174.

NADEAU J, SINGER JB, MATIN A, LANDER ES (2000). Analysing complex genetic traits with chromosome substitution strains. Nat Genet 24: 221-225.

NADEAU JH, TOPOL EJ (2006). The genetics of health. Nat Genet 38: 1095-1098.

NAKOUZI GA, NADEAU JH (2014). Does dietary folic acid supplementation in mouse NTD models affect neural tube development or gamete preference at fertilization? BMC Genetics 15: 91.

NELSON VR, HEANEY JD, TESAR PJ, DAVIDSON NO, NADEAU JH (2012). Transgenerational epigenetic effects of the Apobec1cytidine deaminase deficiency on testicular germ cell tumor sucsceptibility and embryonic viability. Proc Natl Acad Sci USA 109: E2766-2773.

PIERCE, GB JR (1967). Teratocarcinoma: model for a developmental concept of cancer. Cur Topics Dev. Biol 2: 223-246.

ROSENTHALMD, WISHNOW RM, SATO GH (1970). In vitrogrowth and differentiation of clonal populations of multipotential mouse cells derived from a transplantable testicular teratocarcinoma. J Natl Cancer Inst. 44: 1001-1014.

SELL S. (2010). On the stem cell origin of cancer. Am J Pathol.176: 2584-2494.

SHAMBLOTT MJ, AXELMAN J, WANG S, BUGG EM, LITTLEFIELD JW, DONOVAN PJ, BLUMENTHAL PD, HUGGINS GR, GEARHART JD (1998). Derivation of pluripotent stem cells from cultured human primordial germ cells. Proc Natl Acad Sci USA 95: 13726-31.

SHAO H, BURRAGE LC, SINASAC DS, HILL AE, ERNEST SR, O'BRIEN W, COURTLAND HW, JEPSEN KJ, KIRBY A, KULBOKAS EJ, DALY MJ, BROMAN KW, LANDER ES, NADEAU, JH (2008). Genetic architecture of complex traits: large phenotypic effects and pervasive epistasis. Proc Natl Acad Sci USA. 105: 19910-19914.

SHERMAN, MI AND D SOLTER EDS. (1975). Teratomas and Differentiation. Academic Press, NY.

SILVER, LM, MARTIN GR AND S STRICKLAND (EDS.) (1983) Teratocarcinoma Stem Cells. Cold Spring Harbor Laboratory Press.

SLYEM, HOLMES HS, WELLSHG (1919). Primary spontaneous tumors of the testicle and seminal vesicle in mice and other animals: XII, studies in the incidence and inheritability of spontaneous tumors in mice. J Cancer Res 4: 207-228.

SLYLE M, HOLMES HS, WELLS HG (1920). Primary spontaneous tumors of the ovary in mice: Studies on the incidence and inheritability of spontaneous tumors in mice: XIV communication. J. Cancer Res 5: 205-226.

SOLTER D, SKREB N, DAMJANOV I (1970). Extrauterine growth of mouse eggcylinders results in malignant teratoma. Nature 227: 503-504.

SPIEZIO, SH, TAKADA T, SHIROISHI T, NADEAU JH (2012). Genetic divergence and the genetic architecture of complex traits in chromosome substitution strains of mice. BMC Genet 13: 38 .

STEVENS, LC (1958). Studies of transplantable testicular teratomas of strain 129 mice. J Natl Cancer Inst. 20: 1257-1276.

STEVENS LC (1959). Embryology of testicular teratomas in strain 129 mice. J Natl Cancer Inst. 23: 1249-1295.

STEVENS LC (1964). Experimental production of testicular teratomas in mice. Proc Natl Acad Sci USA 52: 654-661.

STEVENS, LC (1966). Development of resistance to teratocarcinogenesis by primordial germ cells in mice. J. Natl Cancer Inst. 37: 859-861.

STEVENS, LC (1967). Origin of testicular teratomas from primordial germ cells in mice. J. Natl. Cancer. Inst.38: 549-52.

STEVENS, LC (1967). The biology of teratomas. Advan. Morph 6: 1-37.

STEVENS, LC (1968). The development of teratomas from intratesticular grafts of tubal mouse eggs. J Embryol Exp Morph 20: 329-341.

STEVENS, LC (1970). Experimental production of testicular teratomas in mice of strains 129, A/He, and their F1 hybrids. J Natl Cancer Inst 44: 929-932.

STEVENS LC (1973). A new inbred subline of mice (129-terSV) with a high incidence of spontaneous congenital testicular teratomas. J Natl Cancer Inst.50: 235-242.

STEVENSLC (1981). Genetic influences of teratocarcinogenesis and parthenogenesis. Prog Clin Biol Res 45: 93-104.

STEVENS, LC (1983). The origin and development of testicular, ovarian, and embryoderived teratomas. In Teratocarcinoma Stem Cells (Eds LM Silver, GR Martin and S Strickland) Cold Spring Harbor Laboratory Press, pp.23-36.

STEVENS, LC, LITTLE CC (1954). Spontaneous testicular tumors in an inbred strain of mice. Proc Natl Acad Sci USA 40: 1080-1087.

STEVENSLC, HUMMEL KP (1957). Adescription of spontaneous congenital testicular teratomas in strain 129 mice. J Natl Cancer Inst 18: 719-747.

STEVENS, LC, MACKENSEN JA (1961). Genetic and environmental influences on teratocarcinogenesis in mice. J Natl Cancer Inst. 27: 443-453.

STEVENS, LC, VARNUM DS (1974). The development of teratomas from parthenogenetically activated ovarian mouse eggs. Dev. Biol 37: 369-380.

STEWARD FC (1964). Growth and development of cultured plant cells Science 143: 20-27.

TANAKA V, NG NCLY, YU, ZY, CASCO-ROBLES MM, MARUUO F, TSONIS PA, CHIBA $C$ (2016). A developmentally regulated switch from stem cells to dedifferentiation for limb muscle regeneration in newts. Nature Comm 7: 11069. 
THOMSON J A, ITSKOVITZ-ELDOR J, SHAPIRO SS, WAKNITZ MA, SWIEGIEL JJ, MARSHALL VS, JONES J M (1998). Embryonic stem cell lines derived from human blastocysts. Science 282: 1145-1147.

TILL JE, MCCULLOUGH EA (1961). A direct measure of the radiation sensitivity of normal mouse bone marrow cells. Radiation Res. 14: 213-222.

YOUNGREN, KK, COVENEY D, PENG X, BHATTACHARYA C, SCHMIDT LS, NICKERSON ML, LAMB BT, DENG JM, BEHRINGER R, CAPEL B, RUBIN M,
NADEAU J, MATINA(2005). The Termutation in the Dead-end gene causes germ cell loss and testicular germ cell tumours. Nature 435: 360-364.

ZECHEL JL, MACLENNAN GT, HEANEY JD, NADEAU JH (2011). Spontaneous metastasis in mouse models of testicular germ-cell tumours. Int JAndro/34 e278-287.

ZECHELJL, DOERNERSK, LAGERA, TESARPJ, HEANERYJD, NADEAUJH(2013). Contrasting effects of Deadend1 (Dnd1) gain and loss of function mutations on allelic inheritance, testicular cancer and intestinal polyposis. BMC Genet 14: 54.

\section{Further Related Reading, published previously in the Int. J. Dev. Biol.}

Testicular teratomas: an intersection of pluripotency, differentiation and cancer biology Ximena Bustamante-Marín, Jason A. Garness and Blanche Capel

Int. J. Dev. Biol. (2013) 57: 201-210

From testis to teratomas: a brief history of male germ cells in mammals

Massimo De Felici and Susanna Dolci

Int. J. Dev. Biol. (2013) 57: 115-121

Mammalian Embryology Conference: celebrating the pioneering work of Andrzej K. Tarkowski (Warsaw, Poland, 25-26 October, 2013) Magdalena Krupa, Aneta Suwinska and Marek Maleszewski

Int. J. Dev. Biol. (2013) 57: 799-808

Stem Cells in Biology and Disease - ESTOOLS International Symposium

Sergio Pistoi

Int. J. Dev. Biol. (2010) 54: 1399-1404

Primordial germ cell biology at the beginning of the XXI Century

Massimo De Felici

Int. J. Dev. Biol. (2009) 53: 891-894

Pluripotency and differentiation in embryos and stem cells - Pavia, 17-18 January 2008 James A. Adjaye, Anne G. Byskov, Jose B. Cibelli, Ruggero De Maria, Stephen Minger, Maurilio Sampaolesi, Giuseppe Testa, Catherine Verfaillie, Magdalena Zernicka-Goetz, Hans Schöler, Michele Boiani, Nicola Crosetto and Carlo A. Redi

Int. J. Dev. Biol. (2008) 52: 801-809

A history of mammalian embryological research.

H Alexandre

Int. J. Dev. Biol. (2001) 45: 457-467

5 yr ISI Impact Factor $(2013)=2.879$

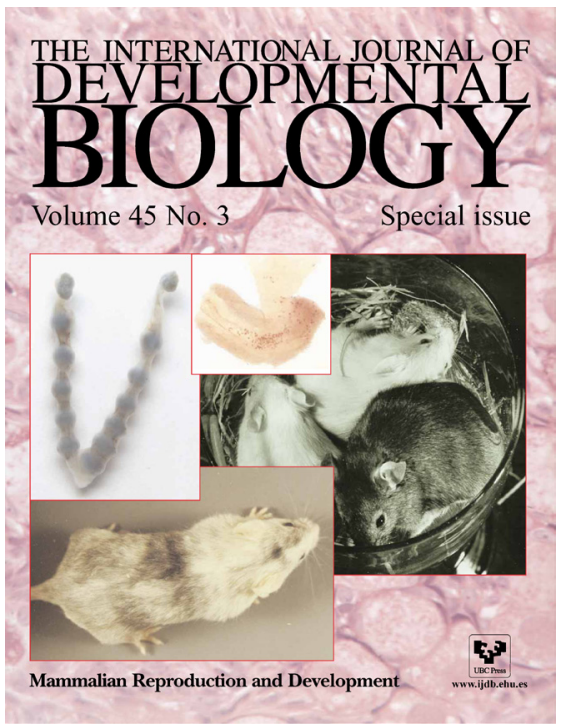

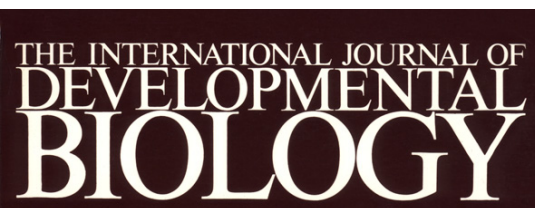

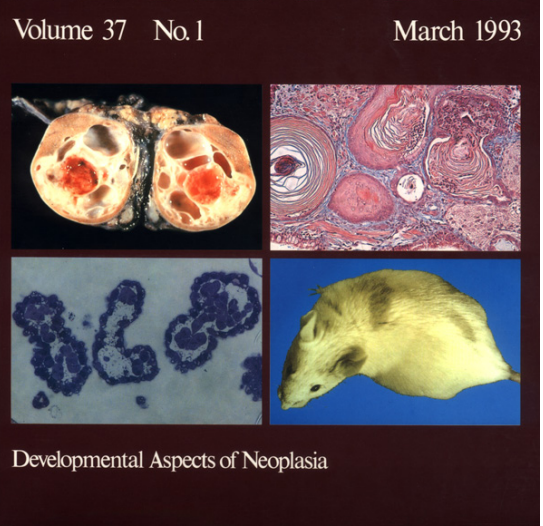

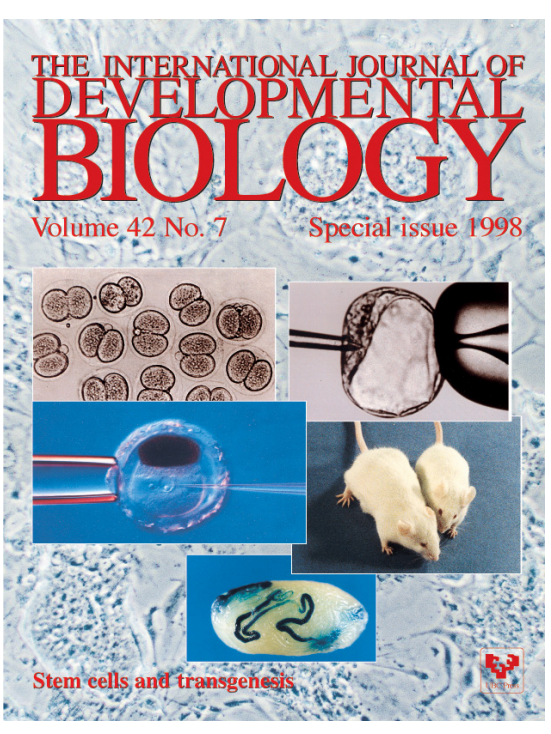

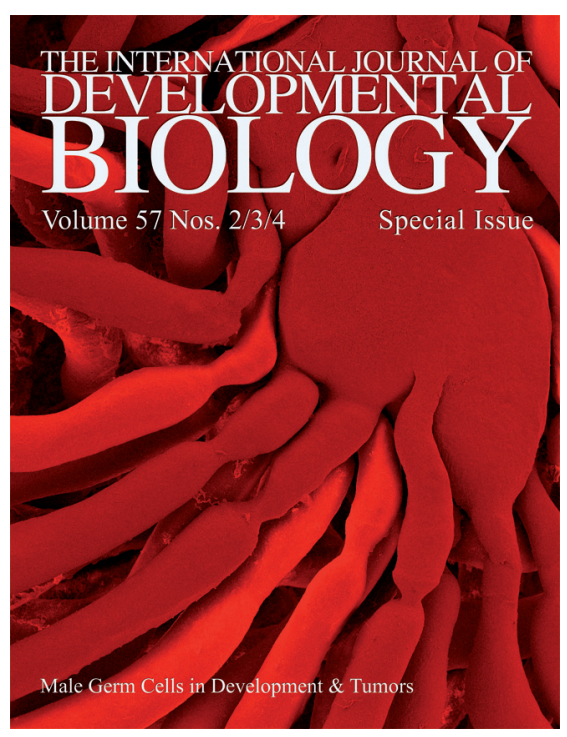

